\title{
Retraction Note: Systematic evaluation of percutaneous radiofrequency ablation versus percutaneous ethanol injection for the treatment of small hepatocellular carcinoma: a meta-analysis
}

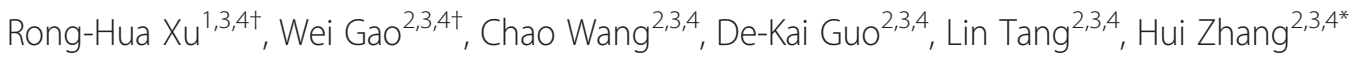 \\ and Cong-Jun Wang $2,3,4^{*}$
}

\section{Retraction}

The Publisher and Editor regretfully retract this article [1] because the peer-review process was inappropriately influenced and compromised. As a result, the scientific integrity of the article cannot be guaranteed. A systematic and detailed investigation suggests that a third party was involved in supplying fabricated details of potential peer reviewers for a large number of manuscripts submitted to different journals. In accordance with recommendations from COPE we have retracted all affected published articles, including this one. It was not possible to determine beyond doubt that the authors of this particular article were aware of any third party attempts to manipulate peer review of their manuscript.

\section{Author details}

'Department of Oncology Surgery, The Affiliated Hospital of Hainan Medica College, 31 Longhua Road, Haikou 570102, Hainan Province, China.

${ }^{2}$ Department of Hepatobiliary and Pancreatic Diseases, Shanghai East Hospital, Tongji University School of Medicine, 150 Jimo Road, Pudong New District, Shanghai 200120, China. ${ }^{3}$ Department of Surgery, University of Michigan Medical School, 1500 E Medical Center Dr., Ann Arbor 48105, MI USA. ${ }^{4}$ Translational Oncology Program, University of Michigan Medical School, 1600 Huron Parkway, Ann Arbor Ml 48109, MI, USA.
Received: 25 January 2015 Accepted: 2 March 2015 Published online: 26 March 2015

\section{Reference}

1. Xu RH, Gao W, Wang C, Guo DK, Tang L, Zhang H, et al. Systematic evaluation of percutaneous radiofrequency ablation versus percutaneous ethanol injection for the treatment of small hepatocellular carcinoma: a meta-analysis. Eur J Med Res. 2014;19:39.

\footnotetext{
*Correspondence: zhangh468@sohu.com; wcongjun@umich.edu ${ }^{\dagger}$ Equal contributors

${ }^{2}$ Department of Hepatobiliary and Pancreatic Diseases, Shanghai East Hospital, Tongji University School of Medicine, 150 Jimo Road, Pudong New District, Shanghai 200120, China

${ }^{3}$ Department of Surgery, University of Michigan Medical School, $1500 \mathrm{E}$ Medical Center Dr., Ann Arbor 48105, MI, USA

${ }^{4}$ Translational Oncology Program, University of Michigan Medical School, 1600 Huron Parkway, Ann Arbor Ml 48109, MI, USA
}

\section{Submit your next manuscript to BioMed Central} and take full advantage of:

- Convenient online submission

- Thorough peer review

- No space constraints or color figure charges

- Immediate publication on acceptance

- Inclusion in PubMed, CAS, Scopus and Google Scholar

- Research which is freely available for redistribution 